\title{
Perkembangan Wilayah, Keselarasan Penggunaan Lahan dengan Pola Ruang, dan Arahan Rencana Pengembangan Wilayah Kabupaten Tangerang
}

\author{
Regional Development, Consistency of Land Use with Spatial Plan, and Direction of \\ Tangerang Regency Regional Development Plan
}

lis Rismawati ${ }^{1}$, Santun R.P. Sitorus ${ }^{2}$, dan Darmawan ${ }^{2}$

Diterima: 25 Maret 2019

Disetujui: 1 April 2020

\begin{abstract}
Abstrak: Kabupaten Tangerang memiliki perekonomian yang didominasi oleh sektor industri. Persebaran penduduk, lokasi permukiman dan industri telah mempengaruhi pola penggunaan lahan dan tingkat perkembangan wilayah Kabupaten Tangerang. Tujuan penelitian ini adalah memberikan arahan rencana pengembangan wilayah di Kabupaten Tangerang dengan mempertimbangkan tingkat perkembangan wilayah, tipologi wilayah; dan keselarasan penggunaan lahan dengan Pola Ruang. Metode yang digunakan adalah analisis skalogram, analisis theil entropi index, analisis kluster, overlay, dan analisis deskriptif. Hasil penelitian menunjukkan bahwa tingkat perkembangan wilayah di kecamatan wilayah bagian selatan lebih tinggi daripada kecamatan di wilayah bagian utara dan ketimpangan tingkat perkembangan wilayah kecamatan di wilayah bagian utara lebih tinggi daripada kecamatan di bagian selatan. Faktor-faktor yang mempengaruhi tingkat perkembangan wilayah adalah persentase luas kawasan pemukiman dan industri, jumlah nilai indeks ekonomi, indeks pendidikan, dan indeks kesehatan. Untuk tipologi wilayah, di wilayah bagian utara, penggunaan lahan didominasi oleh pertanian, sedangkan di wilayah bagian selatan didominasi oleh pemukiman dan industri. Ketidakselarasan penggunaan lahan dengan Pola Ruang sebagian besar ditemukan di wilayah bagian utara. Prioritas pertama dari arahan rencana pengembangan wilayah sebagian besar ditempatkan di bagian utara yang memiliki tingkat perkembangan wilayah rendah, nilai indeks ketimpangan tinggi, persentase ketidakselarasan penggunaan lahan dengan Pola Ruang tinggi, dan penggunaan lahan menunjukan ciri perdesaan.
\end{abstract}

\section{Kata kunci: ketidakselarasan, ketimpangan, perkembangan wilayah}

\begin{abstract}
Tangerang Regency has an economic structure dominated by the industrial sector. Population distribution, settlement location and industrial influenced land use patterns and regional development levels in Tangerang Regency. The objectives of this research are: to analyze the level of regional development and regional development inequality and factors that influence regional development; to analyze regional typology; to evaluate the consistency of land use with the Spatial Planning; and to formulate direction of the Tangerang Regency regional development plan. The method used are scalogram analysis, theil entrophy index analysis, cluster analysis, overlay and descriptive analysis. The results showed that the regional development level of the southern part of the region was higher than the northern part and the level of regional development inequality in the northern part of the region was higher than the southern part. Factors that influence the level of
\end{abstract}

\footnotetext{
${ }^{1}$ Program Studi Ilmu Perencanaan Wilayah, Sekolah Pascasarjana Institut Pertanian Bogor

${ }^{2}$ Departemen Ilmu Tanah dan Sumberdaya Lahan, Fakultas Pertanian, Institut Pertanian Bogor
} 
regional development are the percentage of settlement and industry areas, and the value of economic index, education index, and health index. Concerning typology of the area, in the northern part land use is dominated by agriculture, while in the southern region dominated by settlements and industries. The inconsistency of land use with spatial plan found mostly in the northern region. Thus, the first priority of regional development direction is to be located in the northern part that has a low level of regional development, high inequality value, high percentage of inconsistency of land use with spatial plan, and land use that is dominated by agriculture.

Keywords: inconsistency, inequality, regional development

\section{PENDAHULUAN}

Peraturan Daerah Kabupaten Tangerang Nomor 12 tahun 2009 tentang Rencana Pembangunan Jangka Panjang Daerah (RPJPD) Kabupaten Tangerang Tahun 2005-2025 menetapkan bahwa Kabupaten Tangerang sejak tahun 2015 telah memasuki RPJMD tahapan ketiga (2015-2020) yaitu tahap pemantapan. Peraturan tersebut diantaranya memuat sasaran struktur ruang yang menunjukkan terbentuknya keseimbangan perkembangan antara perkotaan dan perdesaan yang didukung oleh prasarana yang memadai, telematika telah berkembang sampai tingkat perdesaan, dan kegiatan ekonomi utama semakin mendukung perkembangan wilayah (Pemkab Tangerang, 2009).

Kabupaten Tangerang memiliki laju pertambahan penduduk rata-rata 1,03\% per tahun. Perekonomian didominasi oleh sektor industri seperti yang ditunjukan oleh data PDRB tahun 2017 atas dasar harga konstan, terkait industri menempati porsi 39,02\% dengan pertumbuhan 3,63\%, disusul oleh sektor kontruksi/bangunan 12,57\% dengan pertumbuhan $9,92 \%$, dan diikuti oleh perdagangan besar dan eceran, reparasi mobil dan sepeda motor sebesar 11,44\% dengan pertumbuhan 5,41\% (BPS Kabupaten Tangerang, 2018). Kondisi tersebut telah mempengaruhi penggunaan lahan di Kabupaten Tangerang terutama bertambahnya luas permukiman dan kawasan industri yang juga mempengaruhi perkembangan wilayah, sebagaimana pendapat Rustiadi et al. (2011) bahwa seiring dengan laju pertumbuhan penduduk dan ekonomi, akan mempengaruhi penggunaan lahan dan merupakan konsekuensi logis dari adanya pertumbuhan dan transformasi perubahan struktur sosial ekonomi masyarakat yang sedang berkembang. Perkembangan dimaksud tercermin dari adanya: 1) pertumbuhan aktivitas pemanfaatan sumber daya alam akibat meningkatnya permintaan kebutuhan terhadap penggunaan lahan sebagai konsekuensi dari peningkatan jumlah penduduk dan kebutuhan per kapita; 2) adanya pergeseran kontribusi sektor-sektor pertanian dan pengolahan sumber daya alam ke aktivitas sektor-sektor sekunder (manufaktur) dan tersier (jasa), Rudiarto et al. (2017), Eko dan Rahayu (2012), Handayani dan Yuliastuti (2014) menambahkan hal tersebut lebih dominan terjadi pada daerah yang mendekati kawasan perkotaan.

Kabupaten Tangerang sebagai salah satu Kawasan Metropolitan Jabodetabekpunjur memiliki berbagai masalah di antaranya: jumlah infrastruktur cukup bervariasi antar wilayah, lokasi kawasan industri dan permukiman sebagian besar berada di wilayah bagian selatan (BPS Kabupaten Tangerang, 2018), di wilayah bagian utara fasilitas sosial dan fasilitas umum belum memadai (Sumardi, dalam TangerangNews.com, 2018). Hal ini menunjukan adanya perbedaan dan ketimpangan tingkat perkembangan wilayah.

Penggunaan lahan di Kabupaten Tangerang saat ini belum sepenuhnya sesuai dengan yang ditetapkan oleh RTRW pada Peraturan Daerah Kabupaten Tangerang Nomor 13 tahun 2011 tentang Rencana Tata Ruang Wilayah Kabupaten Tangerang tahun 20112031 (Pemkab Tangerang, 2011) diantaranya masih terdapat kawasan industri yang tumbuh dan berkembang di wilayah yang seharusnya wilayah pemukiman (Rushan dalam kompasiana.com, 2015) sehingga diperlukan evaluasi keselarasan penggunaan lahan dengan pola ruang RTRW. 
Tujuan dari penelitian ini adalah, mengetahui tingkat perkembangan wilayah, ketimpangan tingkat perkembangan wilayah, dan faktor-faktor yang mempengaruhi perkembangan wilayah; (2) mengetahui tipologi wilayah; (3) mengevaluasi keselarasan penggunaan lahan dengan pola ruang RTRW; dan (4) menyusun arahan rencana pengembangan wilayah di Kabupaten Tangerang.

\section{METODE PENELITIAN}

Penelitian dilakukan di Kabupaten Tangerang, Provinsi Banten dengan cakupan seluruh kecamatan (29 kecamatan). Pelaksanaan penelitian dimulai pada bulan Juni 2018 sampai Februari 2019. Data yang digunakan dalam penelitian ini terdiri atas data primer dan data sekunder. Data primer didapatkan dari hasil pengamatan lapangan terhadap penggunaan lahan dan lokasi yang tidak selaras dengan pola ruang. Data Sekunder untuk analisis tingkat perkembangan wilayah meliputi data jumlah dan jenis fasilitas, aksesibilitas, dan data jumlah penduduk diperoleh dari BPS Kabupaten Tangerang. Selain itu, data sekunder mencakup Peraturan Daerah tentang RTRW, RPJPD, RPJMD diperoleh dari Badan Perencanaan Pembangunan Daerah dan Dinas Tata Ruang dan Bangunan Kabupaten Tangerang, Peta Penggunaan Lahan tahun 2017 diperoleh dari Kantor Pertanahan (ATR/BPN) Kabupaten Tangerang dan Kementerian Lingkungan Hidup dan Kehutanan. Alat yang digunakan terdiri dari seperangkat komputer dengan perangkat lunak (software) ArcGIS, Statistica 8.0, Eviews, Microsoft Word, Microsoft Excel, GPS, dan kamera digital.

\section{Teknik Analisis Data}

\section{Analisis Tingkat Perkembangan Wilayah}

Tingkat perkembangan wilayah dihitung dengan metode skalogram berbobot (Rustiadi dan Panuju, 2013) sebagai bentuk penyempurnaan atas metode skalogram yang sudah dikembangkan sebelumnya. Jenis data yang digunakan adalah jumlah penduduk, jumlah dan jenis fasilitas pendidikan (jumlah TK/RA, SD/sederajat, SMP/sederajat, SMU/sederajat, SLB, PT, dan Pesantren), jumlah dan jenis fasilitas kesehatan (posyandu, puskesmas, poliklinik, praktek dokter, praktek bidan, RS, RSB, apotek dan toko obat), jumlah dan jenis fasilitas sosial (Masjid, Mushola, Gereja Protestan, Gereja Katolik, Wihara dan Klenteng), serta jumlah dan jenis fasilitas ekonomi (bank, BPR, restoran, hotel, pasar, pertokoan, koperasi, kantor pos, industri, dan persentase jalan yang dilalui angkutan umum), serta jarak/aksesibilitas kecamatan terhadap fasilitas tersebut yang diperoleh dari data Potensi Desa dan Kabupaten Tangerang dalam Angka tahun 2018 (BPS Kabupaten Tangerang, 2018). Persamaan yang digunakan adalah:

dimana:

$$
K_{i j}=\frac{\left(X_{i j}-\min \left(X_{j}\right)\right)}{S_{j}}
$$

$\mathrm{K}_{\mathrm{ij}}$ : nilai baku indeks hirarki untuk kecamatan-i dan fasilitas-j; Min $\left(\mathrm{X}_{\mathrm{j}}\right)$ : nilai minimum indeks fasilitas-j; Sj: nilai standar deviasi fasilitas-j.

Jumlah indeks baku variabel tiap kecamatan disebut dengan Indeks Perkembangan Kecamatan (IPK), nilainya akan menentukan tingkat hierarki wilayah yaitu Wilayah Hierarki I (tingkat perkembangan tinggi): wilayah yang nilai jumlah indeks bakunya paling tidak sama dengan nilai rataan ditambah dengan standar deviasi (IPK > (Stdev+Average)); Wilayah Hierarki II (tingkat perkembangan sedang): Wilayah dengan nilai indeks hirarki lebih dari nilai rataan indeksnya dan kurang dari standar deviasi ditambah rataan 
(averagage $<\mathrm{IPK}<($ Stdev + Average)), dan Wilayah Hierarki III (tingkat perkembangan rendah): Wilayah dengan nilai indeks hirarki kurang dari nilai rataan indeks di seluruh wilayah (IPK<Average) (Panuju dan Rustiadi, 2013).

\section{Analisis Ketimpangan Tingkat Perkembangan Wilayah}

Untuk mengukur nilai indeks ketimpangan tingkat perkembangan wilayah kecamatan digunakan analisis theil entrophy index. Theil entrophy index mampu mengidentifikasi wilayah sumber penyebab ketimpangan pembangunan antar wilayah (Pribadi et al. 2017). Analisis ini dilakukan dengan menggunakan proporsi jumlah penduduk dan nilai indeks perkembangan kecamatan (IPK) tahun 2017 hasil analisis skalogram. Persamaan yang digunakan:

$$
I=\sum\left(\frac{Y i}{Y}\right) \cdot \log \left(\frac{Y i / Y}{X i / X}\right)
$$

dimana :

I : theil entophy index,

Yi: Indeks Perkembangan Kecamatan Wilayah i;

Y: jumlah Indeks Perkembangan Kecamatan Kabupaten Tangerang;

Xi: jumlah penduduk kecamatan wilayah i; X: jumlah penduduk Kabupaten Tangerang.

Untuk memudahkan dalam analisis, hasil nilai indeks ketimpangan dikelompokkan kedalam 3 kategori yaitu: tinggi (nilai indeks ketimpangan> (rata-rata + standar deviasi)), sedang(rata-rata < nilai indeks ketimpangan $<$ (rata-rata + standar deviasi), dan rendah (nilai indeks ketimpangan $\leq$ rata-rata)

\section{Analisis Tipologi Wilayah}

Analisis tipologi Wilayah dilakukan untuk mengetahui wilayah mana saja yang mempunyai ciri perkotaan yaitu wilayah dengan penggunaan lahan didominasi oleh lahan terbangun (permukiman dan industri) dan wilayah yang mempunyai ciri perdesaan atau wilayah yang penggunaan lahannya didominasi lahan tidak terbangun (pertanian, tambak, hutan mangrove). Analisis ini dilakukan dengan menggunakan software statistica $8.0 \mathrm{~d}$ metode Cluster analysis yaitu teknik untuk mengelompokan wilayah berdasarkan karakteristik tertentu dari suatu hamparan wilayah. Teknik ini mengklasifikasikan unit pengamatan dengan karakteristik mirip dalam satu golongan dan unit pengamatan yang berbeda akan diklasifikasikan dalam kelas yang berbeda (Panuju dan Rustiadi, 2013). Unit analisis penelitian ini adalah kecamatan. Variabel parameter penentu tipologi wilayah adalah luas penggunaan lahan yang mendominasi di seluruh kecamatan yaitu permukiman, industri dan pertanian (sawah, pertanian lahan kering, dan pertanian lahan kering campur). Rumus yang digunakan adalah:

$$
D_{i j}=\sqrt{\left(Z_{1 i}^{\prime}-Z_{1 j}^{\prime}\right)^{2}+\left(Z_{2 i}^{\prime}-Z_{2 j}^{\prime}\right)^{2}+\left(Z_{3 i}^{\prime}-Z_{3 j}^{\prime}\right)^{2}}
$$

dimana:

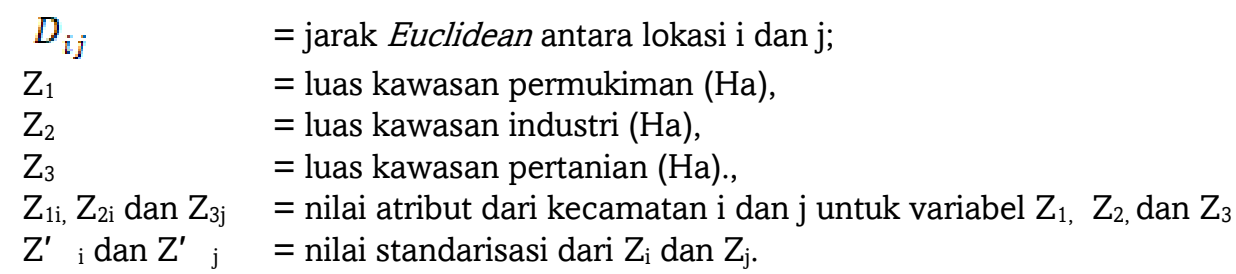




\section{Faktor-faktor yang Mempengaruhi Tingkat Perkembangan Wilayah}

Analisis faktor-faktor yang diduga mempengaruhi tingkat perkembangan wilayah dilakukan menggunakan regresi linier berganda dengan data cross section tahun 2017 sebanyak 29 (sesuai jumlah kecamatan), menggunakan perangkat lunak Eviews. Persamaan yang digunakan yaitu:

dimana :

$$
Y=\alpha+\beta_{1} X_{1}+\beta_{2} X_{2}+\ldots \beta{ }_{12} X_{12}+\varepsilon
$$

Y: variabel independen (IPK);

$\alpha$ : konstanta;

$\beta$ : koefisien regresi;

$\mathrm{X}_{1}$ : persentase luas kawasan permukiman dan industri;

$\mathrm{X}_{2}$ : jumlah indeks fasilitas ekonomi;

$\mathrm{X}_{3}$ : jumlah indeks fasilitas kesehatan;

$\mathrm{X}_{4}$ : jumlah indeks fasilitas pendidikan;

$\mathrm{X}_{5}$ : jumlah indeks fasilitas sosial;

$\mathrm{X}_{6}$ : jarak rata-rata ke pusat kesehatan;

$\mathrm{X}_{7}$ : jarak rata-rata ke pusat pendidikan;

$\mathrm{X}_{8}$ : jarak rata-rata ke pusat pemerintahan;

$\mathrm{X}_{9}$ : jarak rata-rata ke pasar terdekat;

$\mathrm{X}_{10}$ : jumlah IMB;

$\mathrm{X}_{11}$ : persentase jumlah tenaga kerja industri;

$\mathrm{X}_{12}$ : Jumlah penduduk;

$\varepsilon$ : Galat.

\section{Evaluasi Keselarasan Penggunaan Lahan dengan Pola Ruang}

Keselarasan penggunaan lahan dengan pola ruang, merupakan perbandingan antara arahan kawasan menurut tata ruang dengan kondisi existing penggunaan lahan saat ini. Ketidakselarasan penggunaan lahan dengan pola ruang dalam beberapa literatur menyebutnya dengan ketidaksesuaian, inkonsistensi atau penyimpangan (Andrianto et al. (2008) dalam Eko dan Rayahu (2012), Trivinata (2016), Khaerani et al. (2018). Analisis keselarasan penggunaan lahan dilakukan menggunakan aplikasi ArcGis dengan metode overlay Peta Penggunaan Lahan 2017 dengan Peta pola ruang tahun 2011-2031. Klasisfikasi keselarasan terdiri dari 3 kelas yaitu selaras, transisi, dan tidak selaras berdasarkan pertimbangan jenis penggunaan lahan yang sulit atau tidak dapat diubah, baik terkait biaya maupun upaya yang akan dilakukan dan permasalahan-permasalahan sosial yang akan timbul. Penggunaan lahan selaras yaitu penggunaan lahan existing sesuai/sama dengan rencana pola ruang; penggunaan lahan transisi yaitu penggunaan lahan existing masih berbeda dengan rencana pola ruang tetapi ada kemungkinan akan selaras; penggunaan lahan tidak selaras yaitu penggunaan lahan existing berbeda dengan pola ruang dan sulit/tidak dapat diubah menjadi selaras dengan pola ruang (Dani et al. 2017).

Untuk memudahkan dalam kedalam 4 kategori yaitu: tinggi (persentase luas tidak selaras $>$ (rata-rata + standar deviasi)), sedang (rata-rata $<$ persentase luas tidak selaras $<$ (rata-rata + standar deviasi)), dan rendah $(0<$ persentase luas tidak selaras $\leq$ (rata-rata)), dan tidak ada ketidakselarasan (persentase luas tidak selaras $=0$ )

\section{Arahan Rencana Pengembangan Wilayah di Kabupaten Tangerang}

Penentuan arahan rencana pengembangan wilayah dilakukan menggunakan data hasil keseluruhan analisis untuk mengetahui wilayah-wilayah mana yang menjadi prioritas. Teknik yang digunakan adalah analisis deskriptif dengan menyajikan dalam bentuk tabel, 
gambar, atau peta. Data yang belum tersusun rapi memerlukan waktu yang lama dan sulit untuk dianalisis, dengan menyusunnya dalam bentuk yang lebih teratur maka data lebih mudah dianalisis (Ferguson dan Takane 1986, dalam Marzuki 2018). Arahan rencana pengembangan wilayah disusun menjadi 5 prioritas berdasarkan 4 kriteria yaitu tingkat perkembangan wilayah, ketimpangan, penggunaan lahan yang tidak selaras dengan pola ruang, dan kluster.

\section{HASIL DAN PEMBAHASAN}

\section{Tingkat Perkembangan Wilayah}

Hasil perhitungan analisis skalogram menghasilkan nilai Indeks Perkembangan Kecamatan (IPK). Pengelompokan kelas hierarki menghasilkan kecamatan tergolong hierarki I (tingkat perkembangan wilayah tinggi) sebanyak 5 kecamatan (17\%) yaitu 4 kecamatan di wilayah bagian selatan yaitu Balaraja, Cisoka, Kelapa Dua, Panongan, dan 1 kecamatan di wilayah bagian Utara yaitu Kresek, hierarki II (tingkat perkembangan wilayah sedang) sebanyak 11 kecamatan (38\%) terdiri dari 6 kecamatan di wilayah selatan yaitu Tigaraksa, Cikupa, Curug, Jambe, Pagedangan, dan Cisauk, sedangkan di wilayah utara sebanyak 5 kecamatan yaitu Sukamulya, Mauk, Sukadiri, Sepatan dan Kosambi, dan hierarki III (perkembangan wilayah rendah) sebanyak 13 kecamatan (45\%) yang didominasi oleh kecamatan di wilayah utara sebanyak 10 kecamatan yaitu Gunung Kaler, Mekar Baru, Kronjo, Kemiri, Rajeg, Sindang Jaya, Pasar Kemis, Sepatan Timur, Pakuhaji, dan Teluknaga, sedangkan di wilayah selatan hanya sebanyak 3 kecamatan yaitu Jayanti, Solear, dan Legok. Kecamatan yang memiliki kelas hierarki I memiliki nilai Indeks Perkembangan Kecamatan (IPK) tertinggi, dimana fasilitas yang tersedia lebih mampu melayani kebutuhan masyarakat sekitar dengan aksesibilitas yang terjangkau dan mudah, dibandingkan dengan kecamatan lainnya. Peta Tingkat Perkembangan Wilayah disajikan pada Gambar 1.

\section{Ketimpangan Tingkat Perkembangan Wilayah Kabupaten Tangerang}

Hasil analisis ketimpangan tingkat perkembangan wilayah dengan menggunakan theil entrophi index disajikan pada Tabel 1. Jumlah nilai indeks ketimpangan sebesar 0,0627 dengan komposisi di wilayah bagian utara sebesar 0,0496 atau 78,7\% dengan ratarata 0,0050 , lebih tinggi dari wilayah bagian selatan yaitu 0,0131 atau $21,3 \%$ dengan ratarata 0,0033 . Di wilayah bagian utara, kecamatan dengan nilai ketimpangan tertinggi adalah kecamatan Sukadiri $(0,0142)$ dan yang terendah adalah kecamatan Pasar kemis (0,0153 ) sedangkan di wilayah bagian selatan, kecamatan dengan nilai ketimpangan tertinggi adalah kecamatan Jambe $(0,0169)$ dan yang terendah adalah kecamatan Cikupa $(-0,0126)$.

Tabel 1 Hasil Analisis Ketimpangan Tingkat Perkembangan Wilayah

\begin{tabular}{|c|c|c|c|c|}
\hline Kategori & Indeks & $\begin{array}{c}\text { Kecamatan Wilayah Bagian } \\
\text { Utara }\end{array}$ & $\begin{array}{c}\text { Kecamatan Wilayah Bagian } \\
\text { Selatan }\end{array}$ & Jumlah (\%) \\
\hline Tinggi & $\begin{array}{l}0,0102- \\
0,0169\end{array}$ & $\begin{array}{l}\text { Kemiri, Kresek, Mekar Baru, } \\
\text { dan Sukadiri }\end{array}$ & Jambe & $\begin{array}{l}5 \text { Kecamatan } \\
(17 \%)\end{array}$ \\
\hline Sedang & $\begin{array}{l}0,0022- \\
0,0101\end{array}$ & $\begin{array}{l}\text { Gunung Kaler, Kronjo, Mauk, } \\
\text { dan Sukamulya }\end{array}$ & $\begin{array}{l}\text { Balaraja, Cisauk, Cisoka, } \\
\text { Jayanti, dan Solear }\end{array}$ & $\begin{array}{l}9 \text { Kecamatan } \\
(31 \%)\end{array}$ \\
\hline Rendah & $<0,0022$ & $\begin{array}{l}\text { Kosambi, Teluknaga, Sepatan, } \\
\text { Sepatan Timur, Pasar Kemis, } \\
\text { Rajeg, Pakuhaji, dan Sindang } \\
\text { Jaya }\end{array}$ & $\begin{array}{l}\text { Cikupa, Curug, Kelapa Dua, } \\
\text { Legok, Pagedangan, } \\
\text { Panongan, dan Tigaraksa }\end{array}$ & $\begin{array}{l}15 \text { Kecamatan } \\
(52 \%)\end{array}$ \\
\hline Tertinggi & & 0,0142 (Sukadiri) & 0,0169 & \\
\hline
\end{tabular}




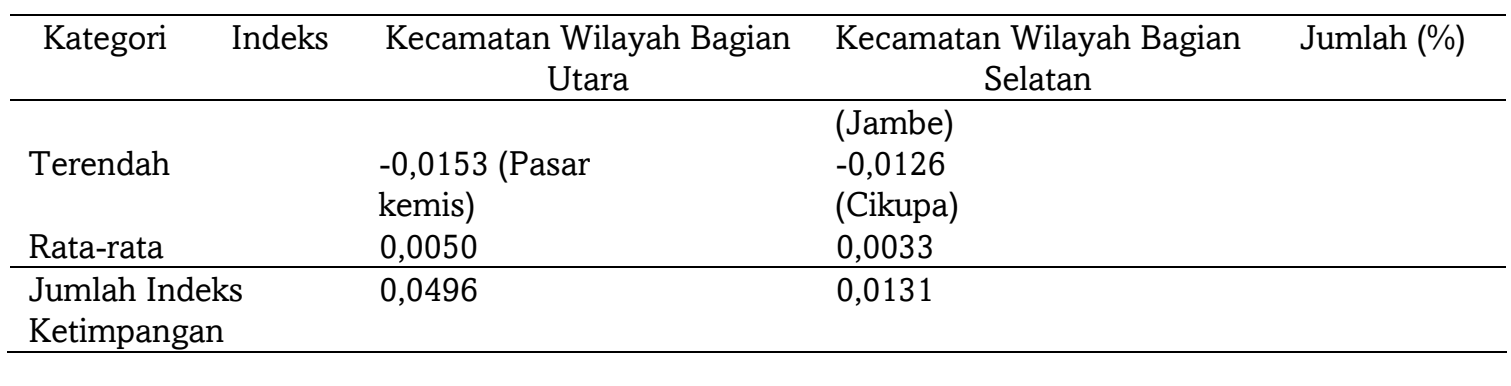

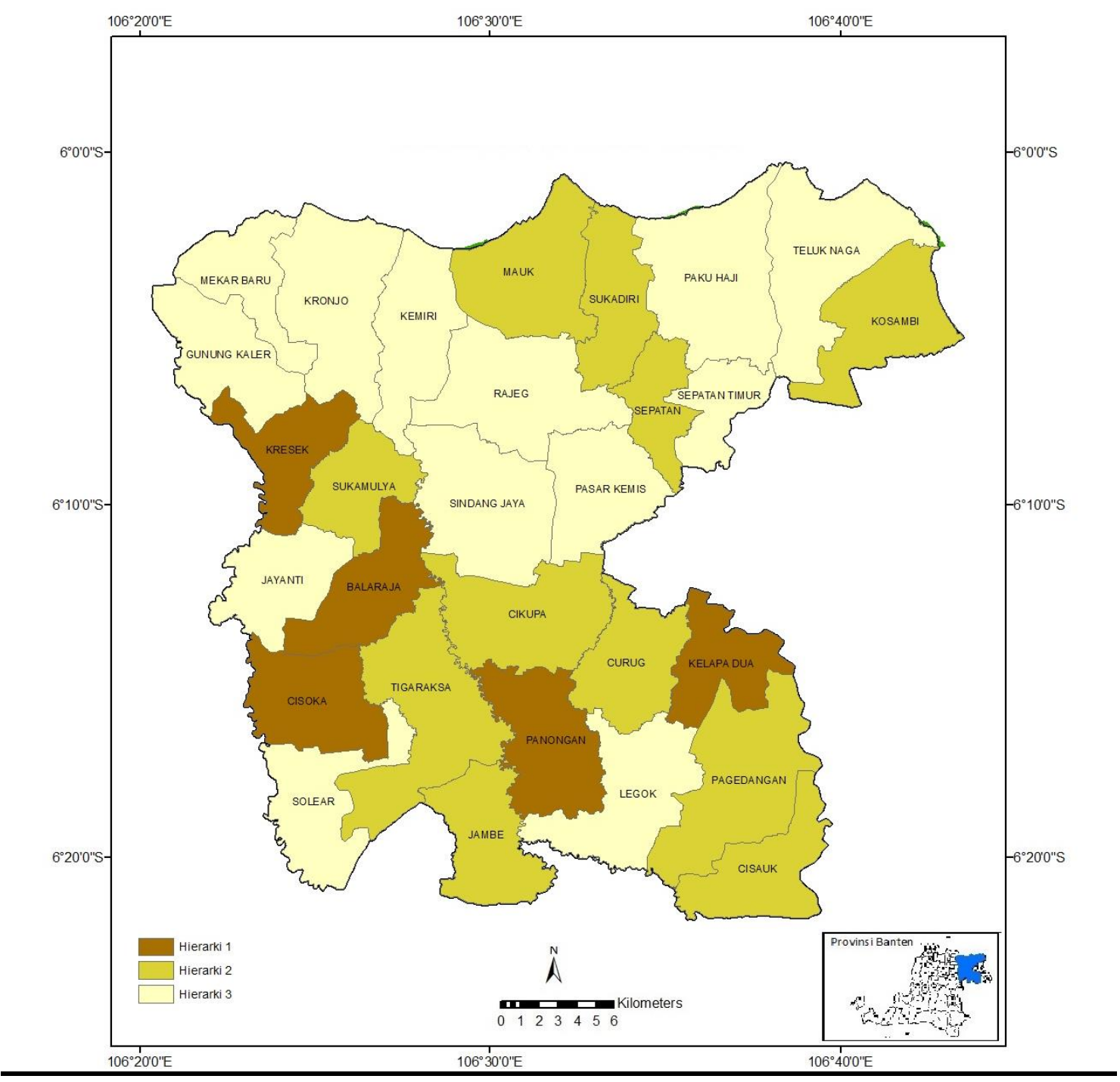

Gambar 1 Peta Tingkat Perkembangan Wilayah di Kabupaten Tangerang

Peta ketimpangan tingkat perkembangan wilayah disajikan pada Gambar 2, yang menunjukan ketimpangan tingkat perkembangan wilayah di Kabupaten Tangerang sebagian besar termasuk kategori rendah yaitu sebanyak 15 Kecamatan (52\%), kategori sedang sebanyak 9 kecamatan (31\%), dan kategori tinggi sebanyak 5 kecamatan (17\%). 


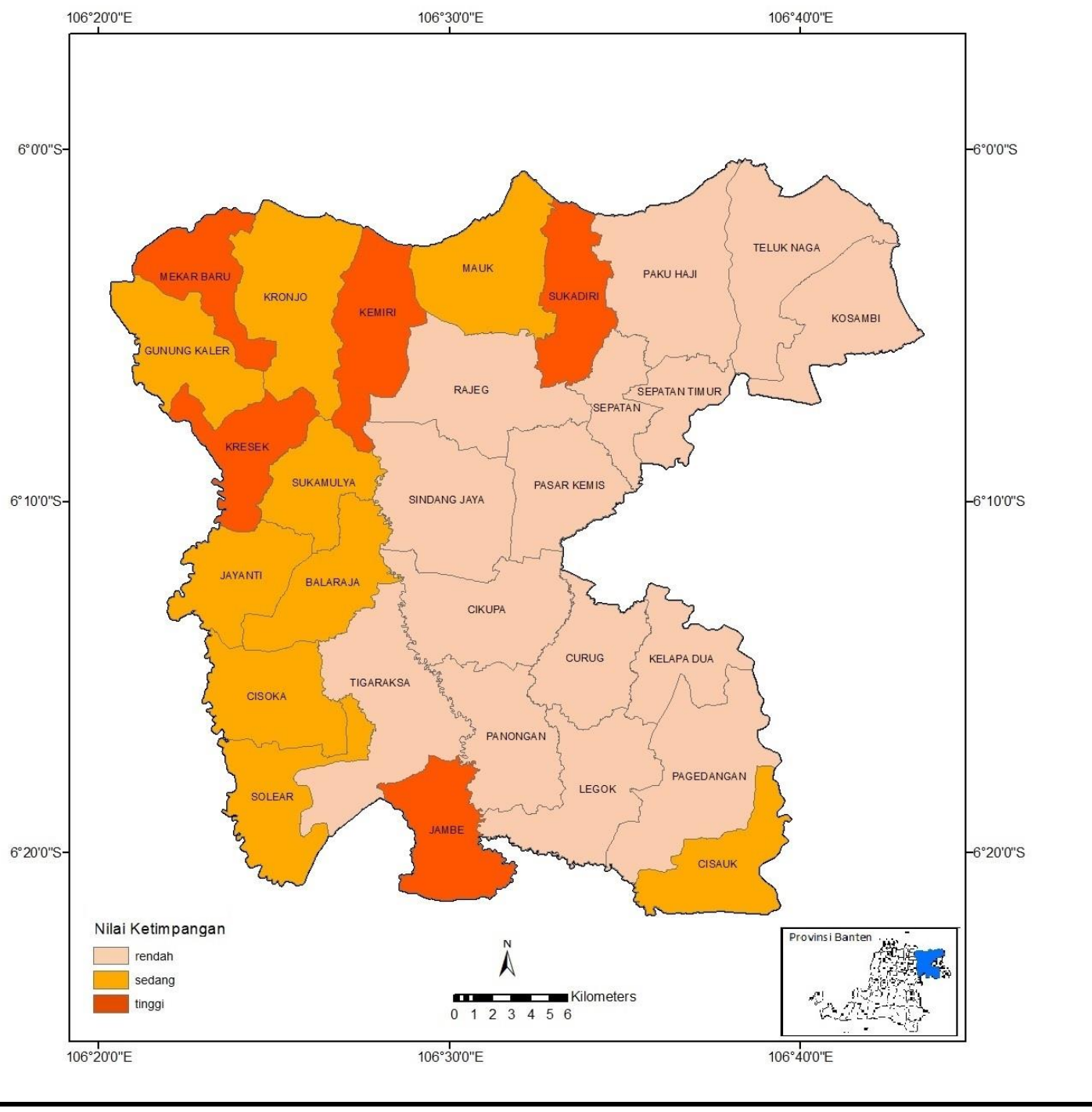

Gambar 2 Peta Ketimpangan Tingkat Perkembangan Wilayah di Kabupaten Tangerang

\section{Faktor-faktor yang Mempengaruhi Tingkat Perkembangan Wilayah}

Hasil regresi linier berganda telah memenuhi uji klasik yang terdiri dari uji multikolinearitas, normalitas, linieritas, dan heteroskedastisitas serta kelayakan model dan mempunyai nilai $R$-Squared sebesar 0,9337 , artinya semua variabel independen dapat menjelaskan variabel dependen sebesar $93,37 \%$. Sisanya yaitu $6,63 \%$ dipengaruhi oleh variabel lain diluar model regresi. Hasil regresi menunjukan faktor-faktor yang berpengaruh signifikan terhadap tingkat perkembangan wilayah yaitu: Persentase luas kawasan permukiman dan industri $\left(\mathrm{X}_{1}\right)$, jumlah indeks fasilitas ekonomi $\left(\mathrm{X}_{2}\right)$, jumlah indeks fasilitas kesehatan $\left(\mathrm{X}_{3}\right)$ dan jumlah indeks fasilitas pendidikan $\left(\mathrm{X}_{4}\right)$, dengan persamaan: $\mathrm{Y}=10,1904+0,1766 \mathrm{X}_{1}+0,8848 \mathrm{X}_{2}+1,0168 \mathrm{X}_{3}+1,2587 \mathrm{X}_{4}$

Persamaan tersebut menunjukan koefisien regresi bernilai positif, artinya jika persentase luas kawasan permukiman dan industri meningkat $1 \%$ maka tingkat perkembangan wilayah akan meningkat sebesar 0,1766, jika jumlah indeks fasilitas ekonomi meningkat 1 satuan maka tingkat perkembangan wilayah akan meningkat 0,8848 , begitu juga untuk fasilitas kesehatan dan fasilitas pendidikan meningkat 1 satuan maka tingkat perkembangan wilayah akan meningkat sebesar 1,0168 dan 1,2587. 


\section{Tipologi Wilayah Kabupaten Tangerang}

Hasil dari analisis cluster yaitu klaster 1 berupa wilayah dengan ciri perkotaan berupa wilayah didominasi penggunaan lahan terbangun (permukiman dan industri) sebanyak 8 kecamatan (28\%) yang sebagian besar berada di wilayah bagian selatan (6 kecamatan) yaitu kecamatan Cikupa, Curug, Kelapa Dua, Legok, Balaraja, dan Sepatan, sedangkan di wilayah bagian utara terdiri dari 2 kecamatan yaitu Kecamatan Pasar Kemis dan Kosambi. klaster 2 berupa wilayah dengan ciri perdesaan yaitu wilayah didominasi oleh lahan tidak terbangun (pertanian, tambak, hutan mangrove) sebanyak 21 kecamatan (72\%) yaitu Kecamatan Cisoka, Solear, Jambe, Cisauk, Jayanti, Sukamulya, Kresek, Gunung Kaler, Mekarbaru, Kemiri, Sukadiri, Sepatan, Sepatan Timur, Teluk Naga, Tigaraksa, Pagedangan, Sindang Jaya, Rajeg, Mauk, Kronjo, dan Pakuhaji. Kecamatan di Wilayah bagian utara hampir seluruhnya termasuk tipologi wilayah dengan ciri perdesaan sedangkan kecamatan di wilayah bagian selatan memiliki tipologi yang hampir seimbang antara wilayah dengan ciri perdesaan dan wilayah dengan ciri perkotaan. Peta Tipologi Wilayah Kabupaten Tangerang di sajikan dengan Gambar 3.

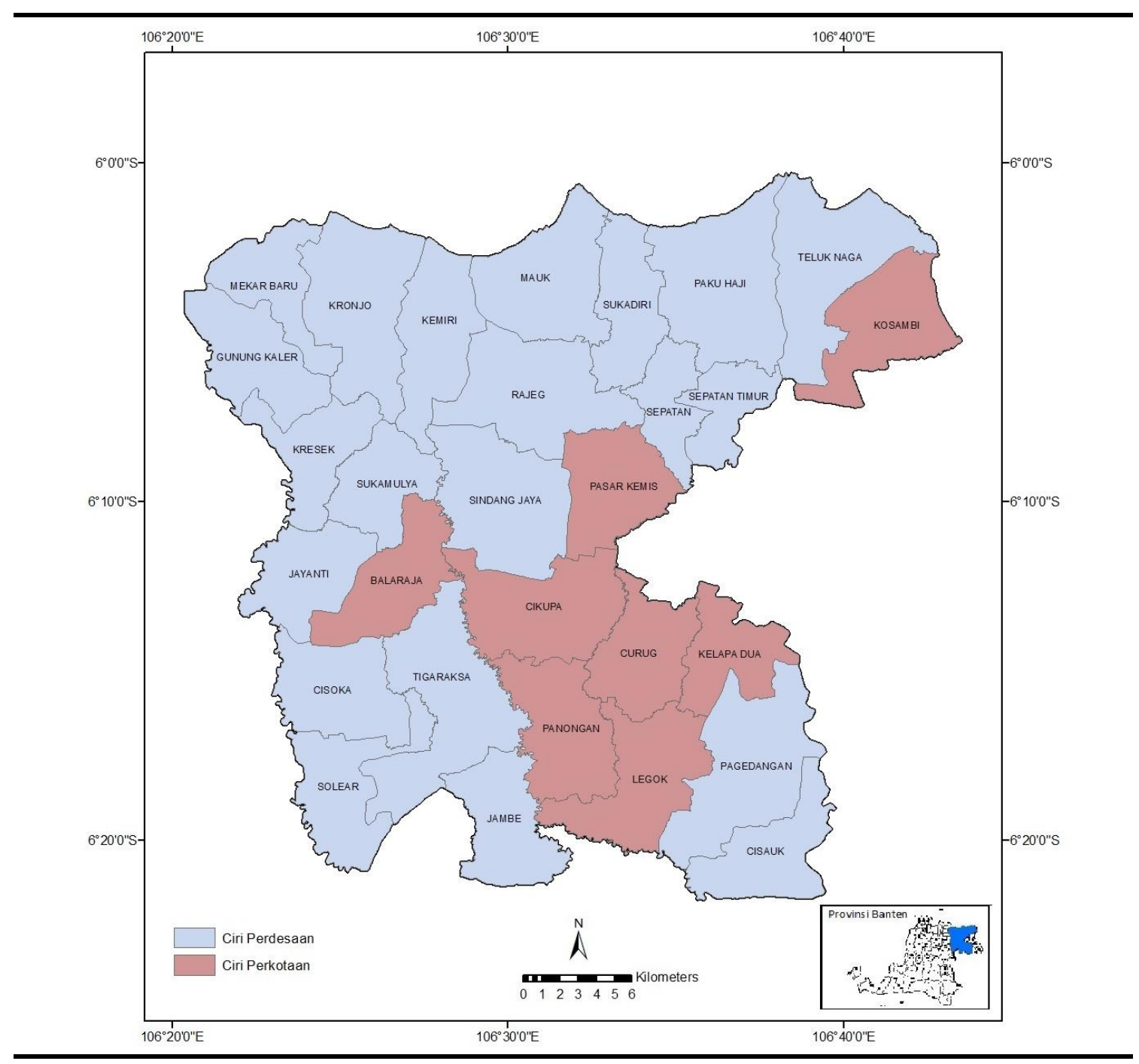

Gambar 3 Peta Tiopologi Wilayah di Kabupaten Tangerang 


\section{Evaluasi Keselarasan Penggunaan Lahan dengan Pola Ruang}

Evaluasi penggunaan lahan exsisting terhadap rencana pola ruang dilakukan dengan melakukan overlay peta penggunaan lahan Kabupaten Tangerang tahun 2017 dengan peta rencana pola ruang Kabupaten Tangerang tahun 2011-2031. Luas keselarasan penggunaan lahan dengan pola ruang disajikan pada Tabel 2, yang menunjukan bahwa di Kabupaten Tangerang penggunaan lahan tergolong selaras seluas 54.552,8 ha (52,8\%), 47.420,7 ha $(45,9 \%)$ merupakan penggunaan lahan transisi, dan hanya $1.291,5$ ha $(1,3 \%)$ wilayah yang penggunaan lahannya tidak selaras dengan pola ruang.

Tabel 2 Luas Keselarasan Penggunaan Lahan dengan Pola Ruang

\begin{tabular}{|c|c|c|c|c|c|c|c|}
\hline \multirow[t]{2}{*}{ No } & \multirow[t]{2}{*}{ Kecamatan } & \multicolumn{2}{|c|}{ Selaras } & \multicolumn{2}{|c|}{ Transisi } & \multicolumn{2}{|c|}{ Tidak Selaras } \\
\hline & & ha & $\%$ & ha & $\%$ & ha & $\%$ \\
\hline 1 & Cisoka & $1.368,2$ & 40,7 & $1.986,8$ & 59,2 & 3,0 & 0,1 \\
\hline 2 & Solear & $1.264,8$ & 38,6 & $1.970,5$ & 60,2 & 37,7 & 1,2 \\
\hline 3 & Tigaraksa & $1.005,1$ & 18,5 & $4.437,9$ & 81,5 & 0,0 & 0,0 \\
\hline 4 & Jambe & 131,2 & 4,4 & $2.877,8$ & 95,6 & 0,0 & 0,0 \\
\hline 5 & Cikupa & $2.989,2$ & 69,3 & $1.313,7$ & 30,5 & 11,2 & 0,3 \\
\hline 6 & Panongan & 905,7 & 24,9 & $2.734,3$ & 75,1 & 0,0 & 0,0 \\
\hline 7 & Curug & $2.093,1$ & 69,5 & 917,9 & 30,5 & 0,0 & 0,0 \\
\hline 8 & Kelapa Dua & $1.936,7$ & 77,2 & 571,3 & 22,8 & 0,0 & 0,0 \\
\hline 9 & Legok & $1.497,7$ & 37,6 & $2.488,3$ & 62,4 & 0,0 & 0,0 \\
\hline 10 & Pagedangan & $1.218,2$ & 23,8 & $3.891,8$ & 76,2 & 0,0 & 0,0 \\
\hline 11 & Cisauk & 858,8 & 28,9 & $2.108,2$ & 71,1 & 0,0 & 0,0 \\
\hline 12 & Pasar Kemis & $2.706,2$ & 84,0 & 480,1 & 14,9 & 35,7 & 1,1 \\
\hline 13 & Sindang Jaya & $1.494,9$ & 31,2 & $3.293,0$ & 68,8 & 0,1 & 0,0 \\
\hline 14 & Balaraja & $1.178,3$ & 37,4 & $1.969,5$ & 62,6 & 0,2 & 0,0 \\
\hline 15 & Jayanti & $1.163,5$ & 40,5 & $1.662,5$ & 57,9 & 46,0 & 1,6 \\
\hline 16 & Sukamulya & $1.450,8$ & 57,3 & $1.075,7$ & 42,5 & 7,5 & 0,3 \\
\hline 17 & Kresek & $1.958,8$ & 74,1 & 624,0 & 23,6 & 60,1 & 2,3 \\
\hline 18 & Gunung Kaler & $2.639,4$ & 80,1 & 448,4 & 13,6 & 207,3 & 6,3 \\
\hline 19 & Kronjo & $3.775,6$ & 77,8 & 735,9 & 15,2 & 338,5 & 7,0 \\
\hline 20 & Mekar Baru & $1.895,3$ & 74,6 & 486,4 & 19,1 & 158,2 & 6,2 \\
\hline 21 & Mauk & $2.537,1$ & 61,3 & $1.335,0$ & 32,2 & 270,0 & 6,2 \\
\hline 22 & Kemiri & $2.611,3$ & 75,8 & 418,1 & 12,1 & 414,5 & 12,0 \\
\hline 23 & Sukadiri & $2.109,9$ & 74,6 & 647,7 & 22,9 & 70,5 & 2,5 \\
\hline 24 & Rajeg & $3.003,6$ & 63,6 & $1.645,2$ & 34,8 & 77,3 & 1,6 \\
\hline 25 & Sepatan & $1.172,5$ & 62,3 & 658,5 & 35,0 & 52,0 & 2,8 \\
\hline 26 & Sepatan Timur & $1.226,2$ & 66,4 & 593,8 & 32,2 & 26,0 & 1,4 \\
\hline 27 & Pakuhaji & $3.611,0$ & 67,6 & $1.334,0$ & 25,0 & 398,1 & 7,5 \\
\hline 28 & Teluknaga & $2.656,4$ & 54,3 & $1.666,3$ & 34,1 & 567,2 & 11,6 \\
\hline 29 & Kosambi & $2.093,6$ & 57,3 & $1.507,7$ & 41,3 & 50,8 & 1,4 \\
\hline & Jumlah & $54.552,8$ & 52,8 & $45.880,3$ & 44,4 & $2.831,9$ & 2,7 \\
\hline
\end{tabular}

Untuk penggunaan lahan transisi yaitu penggunaan lahan pertanian (pertanian lahan basah atau sawah, pertanian lahan kering, dan pertanian lahan kering campur) yang diperuntukan kawasan permukiman, hutan lindung, bandara, industri, industri maritim, pusat pemerintahan, dan tambak, juga kawasan tambak yang diperuntukan kawasan permukiman, hutan lindung dan industri, serta kawasan permukiman yang diperuntukan kawasan industri dan industri maritim. Penggunaan lahan transisi yang sebagian besar berada di wilayah bagian selatan berupa lahan pertanian yang diperuntukan kawasan 
permukiman seluas $38.106,4$ ha $(36,9 \%)$ dan lahan pertanian yang diperuntukan kawasan industri seluas 5.859,79 ha (5,9\%) sebagaimana disajikan pada Tabel 3 .

Tabel 3 Penggunaan Lahan Transisi

\begin{tabular}{llr}
\hline Penggunaan Lahan & Rencana Pola Ruang & Luas (ha) \\
\hline Pertanian (sawah) & Permukiman & $38.106,4$ \\
Pertanian (sawah) & Kawasan Bandara & 1,0 \\
Pertanian (sawah) & Kawasan Industri & $5.859,8$ \\
Pertanian (sawah) & Kawasan Industri Maritim & 202,1 \\
Pertanian (sawah) & Kawasan Pusat Pemerintahan & 9,1 \\
Pertanian (sawah) & Kawasan Tambak & 35,7 \\
Tambak (sawah) & Permukiman & $1.349,2$ \\
Tambak (sawah) & Kawasan Industri & 316,9 \\
\hline Jumlah & & $45.880,3$ \\
\hline
\end{tabular}

Penggunaan lahan yang tidak selaras yaitu 2.831,9 ha didominasi oleh penggunaan lahan tambak untuk hutan lindung sebesar $1.539,0$ ha $(1,5 \%)$ penggunaan lahan permukiman yang diperuntukan untuk pertanian yaitu sebesar $1.218,2$ ha $(1,2 \%)$ disajikan pada Tabel 4.

Tabel 4 Penggunaan Lahan Tidak Selaras dengan Pola Ruang

\begin{tabular}{llr}
\hline Penggunaan Lahan & Rencana Pola Ruang & Luas (ha) \\
\hline Industri & Kawasan Permukiman & 11,4 \\
Permukiman & Kawasan Pertanian & $1.218,2$ \\
Permukiman & Kawasan Tambak & 4,7 \\
Permukiman & Kawasan Hutan Lindung & 0,3 \\
Permukiman & Kawasan Industri Maritim & 56,9 \\
Pertanian (sawah) & Hutan Lindung & 1,4 \\
Tambak & Hutan Lindung & $1.539,0$ \\
\hline Jumlah & & $2.831,9$ \\
\hline
\end{tabular}

Peta Keselarasan Penggunaan Lahan dengan Pola Ruang disajikan pada Gambar 4, yang menunjukan wilayah yang tidak selaras hampir seluruhnya berada di kecamatan bagian utara yang tingkat perkembangan wilayahnya rendah sampai sedang, dan hanya sebagian kecil yang berada di wilayah bagian selatan. Persentase luas penggunaan lahan yang tidak selaras terbesar adalah kecamatan Gunung Kaler yaitu 6,3\% dari luas wilayahnya.

\section{Arahan Rencana Pengembangan Wilayah Kabupaten Tangerang}

Wilayah yang diprioritaskan untuk dikembangkan berdasarkan 4 kriteria yaitu tingkat perkembangan wilayah, ketimpangan, penggunaan lahan yang tidak selaras dengan pola ruang dan tipologi wilayah. Kecamatan yang menjadi prioritas I (pertama) yaitu memiliki tingkat perkembangan wilayah rendah, nilai indeks ketimpangan tingkat perkembangan wilayah tinggi, persentase ketidakselarasan penggunaan lahan dengan pola ruang tinggi dan tipologi wilayah dengan ciri perdesaan. Kecamatan dan kriteria prioritas pengembangan wilayah disajikan pada Tabel 5 . 


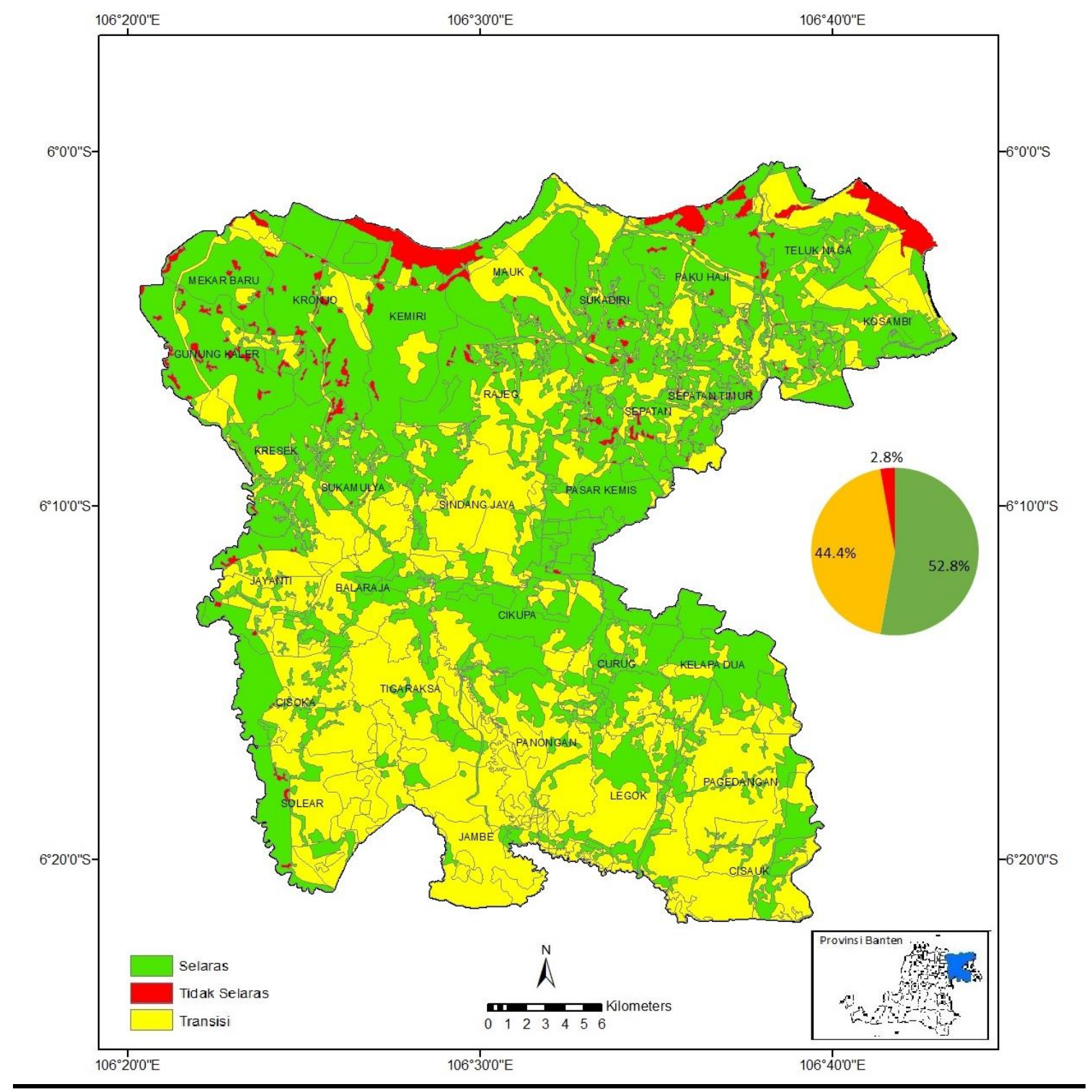

Gambar 4 Peta Keselarasan Penggunaan Lahan dengan Pola Ruang

Tabel 5 Kecamatan dan Kriteria Arahan Prioritas Pengembangan Wilayah

\begin{tabular}{llllll}
\hline Prioritas & Kecamatan & Hierarki & Ketimpangan & Tipologi & $\begin{array}{l}\text { Penggunaan } \\
\text { Lahan Tidak } \\
\end{array}$ \\
& & & & Selaras \\
\hline I & Mekar Baru & Rendah & Tinggi & Ciri Perdesaan & Tinggi \\
I & Kemiri & Rendah & Tinggi & Ciri Perdesaan & Tinggi \\
I & Gunung Kaler & Rendah & Sedang & Ciri Perdesaan & Tinggi \\
I & Kronjo & Rendah & Sedang & Ciri Perdesaan & Tinggi \\
I & Jayanti & Rendah & Sedang & Ciri Perdesaan & Rendah \\
I & Solear & Rendah & Sedang & Ciri Perdesaan & Rendah \\
\hline II & Pakuhaji & Rendah & Rendah & Ciri Perdesaan & Tinggi \\
II & Teluknaga & Rendah & Rendah & Ciri Perdesaan & Tinggi \\
II & Pasar Kemis & Rendah & Rendah & Ciri Perkotaan & Rendah \\
II & Rajeg & Rendah & Rendah & Ciri Perdesaan & Rendah
\end{tabular}




\begin{tabular}{llllll}
\hline Prioritas & Kecamatan & Hierarki & Ketimpangan & Tipologi & $\begin{array}{l}\text { Penggunaan } \\
\text { Lahan Tidak } \\
\text { Selaras }\end{array}$ \\
\hline II & Sepatan & Rendah & Rendah & Ciri Perdesaan & Rendah \\
& Timur & Rendah & Rendah & Ciri Perkotaan & Tidak ada \\
II & Legok & Ren & Ciri Perdesaan & Tidak ada \\
II & Sindang Jaya & Rendah & Rendah & Ciri Perdesaan & Tidak ada \\
III & Jambe & Sedang & Tinggi & Ciri Perdesaan & Sedang \\
III & Sukadiri & Sedang & Tinggi & Ciri Perdesaan & Tinggi \\
III & Mauk & Sedang & Sedang & Ciri Perkotaan & Sedang \\
III & Sepatan & Sedang & Rendah & Ciri Perdesaan & Rendah \\
III & Sukamulya & Sedang & Sedang & Ciri Perdesaan & Tidak ada \\
III & Cisauk & Sedang & Sedang & Ciri Perkotaan & Rendah \\
\hline IV & Cikupa & Sedang & Rendah & Ciri Perkotaan & Rendah \\
IV & Kosambi & Sedang & Rendah & Ciri Perkotaan & Tidak ada \\
IV & Curug & Sedang & Rendah & Ciri Perdesaan & Tidak ada \\
IV & Pagedangan & Sedang & Rendah & Ciri Perdesaan & Tidak ada \\
IV & Tigaraksa & Sedang & Rendah & Ciri Perdesaan & Rendah \\
\hline V & Kresek & Tinggi & Tinggi & Ciri Perdesaan & Rendah \\
V & Cisoka & Tinggi & Sedang & Ciri Perkotaan & Tidak ada \\
V & Balaraja & Tinggi & Sedang & Ciri Perdesaan & Tidak ada \\
V & Panongan & Tinggi & Rendah & Ciri Perkotaan & Tidak ada \\
V & Kelapa Dua & Tinggi & Rendah & & \\
\hline & & & & & \\
\hline
\end{tabular}

Dari Tabel 5 terlihat prioritas pengembangan I sebanyak 6 Kecamatan (21\%) yaitu Kecamatan Mekar Baru, Kemiri, Gunung Kaler, Kronjo, Jayanti, dan Solear, prioritas pengembangan II sebanyak 7 kecamatan (24\%) yaitu Kecamatan Pakuhaji, teluknaga, Pasar Kemis, Rajeg, Sepatan Timur, Legok, dan Sindang Jaya, prioritas pengembangan III sebanyak 6 Kecamatan (21\%) yaitu kecamatan Sukadiri, Mauk, Sepatan, Sukamulya, dan Cisauk, prioritas pengembangan IV sebanyak 5 Kecamatan $(17 \%)$ yaitu kecamatan Cikupa, Kosambi, Curug, Pagedangan, dan Tigaraksa, dan prioritas pengembangan $\mathrm{v}$ sebanyak 5 Kecamatan (17\%) yaitu Kecamatan Kresek, Cisoka, Balaraja, Panongan, dan Kelapa Dua. Peta Arahan Rencana Pengembangan Wilayah Kabupaten Tangerang disajikan pada Gambar 5.

Sesuai dengan hasil analisis faktor-faktor yang mempengaruhi perkembangan wilayah, yaitu persentase luas kawasan permukiman dan industri, jumlah indeks fasilitas ekonomi, jumlah indeks fasilitas kesehatan, dan jumlah indeks fasilitas pendidikan, maka pengembangan wilayah dilakukan dengan meningkatkan pemberian izin lokasi perumahan dan industri di lokasi yang luas permukimannya masih sedikit dengan tetap berpedoman pada RTRW, meningkatkan jumlah dan jenis fasilitas ekonomi, fasilitas kesehatan dan fasilitas pendidikan. Peningkatan fasilitas ekonomi menjadi yang utama agar tercipta pusat pertumbuhan baru, sesuai dengan konsep kutub pertumbuhan Perroux bahwa pertumbuhan disebarkan dari kutub pertumbuhan ke wilayah disekitarnya dalam sistem ekonomi (Parr 1999 dalam Marzuki, 2018).

Arahan prioritas rencana pengembangan wilayah ini diharapkan dapat mewujudkan sasaran pembangunan Kabupaten Tangerang yaitu terbentuknya keseimbangan perkembangan antara perkotaan dan perdesaan yang didukung oleh prasarana yang memadai, telematika telah berkembang sampai tingkat perdesaan, dan 
kegiatan ekonomi utama semakin mendukung perkembangan wilayah, dan sesuai dengan arah kebijakan Kabupaten Tangerang yaitu pembangunan pengembangan pertanian berbasis agribisnis dan agroindustri, serta pengembangan perekonomian mengarah pada peningkatan struktur industri sebagaimana ditetapkan dalam Peraturan Daerah Kabupaten Tangerang Nomor 12 tahun 2009 tentang Rencana Pembangunan Jangka Panjang Daerah (RPJPD) Kabupaten Tangerang Tahun 2005-2025 (Pemkab Tangerang, 2009).

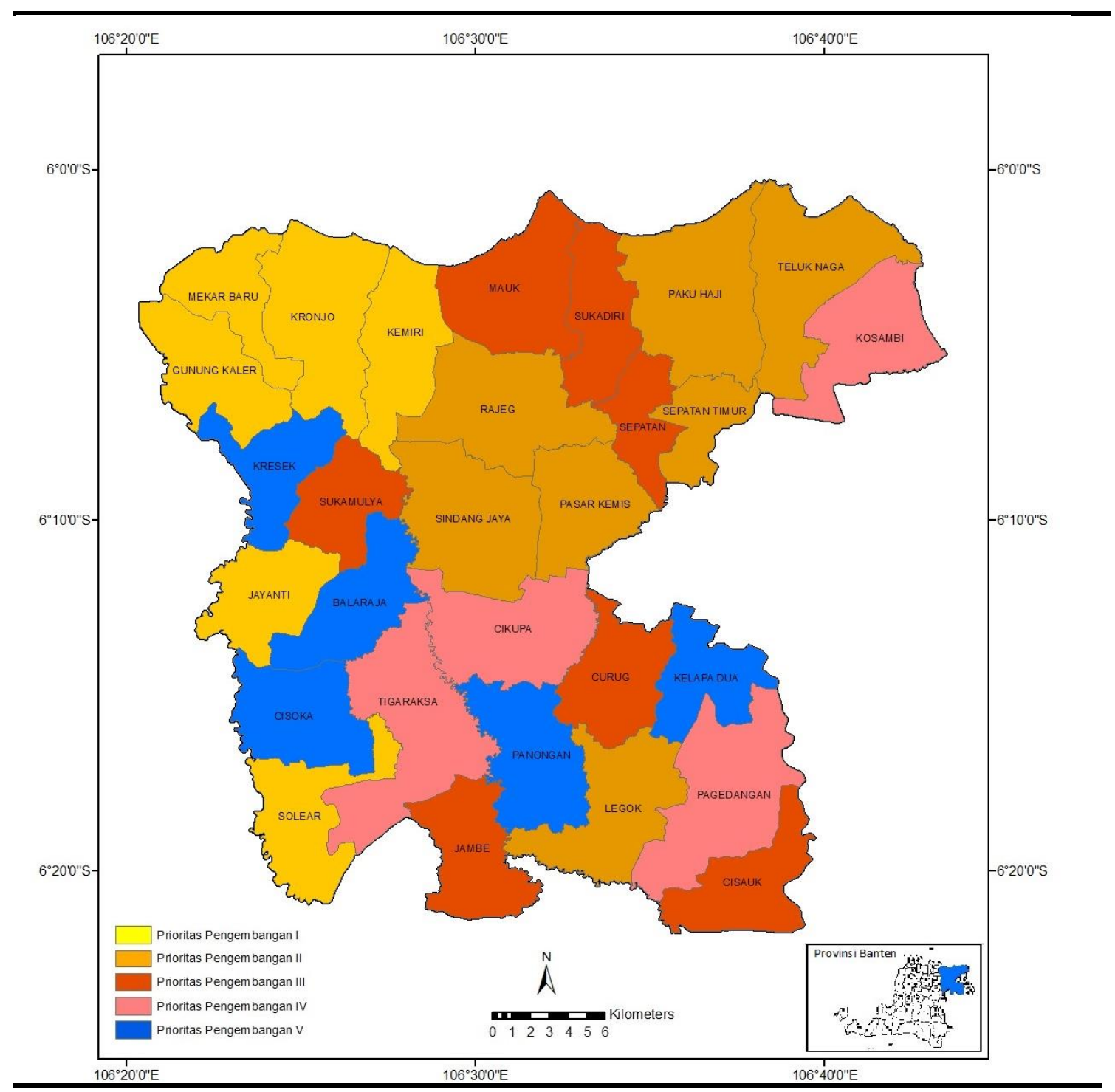

Gambar 5 Peta Arahan Rencana Pengembangan Wilayah Kabupaten Tangerang

\section{KESIMPULAN}

Tingkat perkembangan wilayah kecamatan di Kabupaten Tangerang dengan tingkat perkembangan wilayah tinggi dan sedang sebagian besar berada di wilayah bagian selatan, sedangkan di wilayah bagian utara sebagian besar termasuk tingkat perkembangan wilayah rendah. Ketimpangan perkembangan wilayah di wilayah bagian utara lebih tinggi dari wilayah bagian selatan. Faktor-faktor yang secara signifikan mempengaruhi tingkat perkembangan wilayah adalah persentase luas kawasan permukiman dan industri, jumlah 
indeks fasilitas ekonomi, jumlah indeks fasilitas kesehatan, dan jumlah indeks fasilitas pendidikan. Tipologi Wilayah Kabupaten Tangerang di kecamatan wilayah bagian utara hampir seluruhnya merupakan tipologi wilayah dengan ciri perdesaan, sedangkan di kecamatan wilayah bagian selatan, memiliki komposisi yang hampir seimbang antara wilayah dengan ciri perdesaan dan wilayah dengan cirri perkotaan. Penggunaan lahan di Kabupaten Tangerang sebagian besar tergolong selaras dan transisi, hanya sebagian kecil yang tidak selaras dengan pola ruang RTRW. Yang menjadi prioritas I (pertama) dalam arahan rencana pengembangan wilayah Kabupaten Tangerang yaitu kecamatan yang memiliki tingkat perkembangan wilayah rendah, nilai indeks ketimpangan tingkat perkembangan wilayah tinggi, persentase ketidakselarasan penggunaan lahan dengan pola ruang tinggi dan tipologi wilayah dengan ciri perdesaan. Kecamatan yang menjadi prioritas I, II, dan III sebagian besar berada di kecamatan wilayah bagian utara, sedangkan untuk prioritas IV dan V sebagian besar berada di kecamatan wilayah bagian selatan.

\section{DAFTAR PUSTAKA}

[BPS] Badan Pusat Statistik Kabupaten Tangerang. 2018. Kabupaten Tangerang dalam Angka. Tangerang (ID): BPS Kabupaten Tangerang.

Dani ET, Sitorus SRP, Munibah K. 2017. Analisis Penggunaan Lahan dan arahan Pengendalian Pemanfaatan Ruang di Kabupaten Bogor. Jurnal Tata Loka. 19(1): 40-52.

Eko T, Rahayu S. 2012. Perubahan Penggunaan Lahan dan Kesesuaiannya dengan RDTR di Wilayah Peri Urban (Studi Kasus Kecamatan Mlati). Jurnal Pembangunan Wilayah dan Kota. 8 (4): 330-340.

Handayani AD, Yuliastuti N. 2014. Identifikasi Ketersediaan dan Kualitas Sarana Prasarana Lingkungan di Urban Fringe Area Kelurahan Pudakpayung. Jurnal Wilayah dan Lingkungan. 2 (3): 197-208.

Khaerani R, Sitorus SRP, Rusdiana O. 2018. Analisis Penyimpangan Penggunaan Lahan berdasarkan Rencana Tata Ruang Kabupaten Sumedang. Jurnal Tata Loka. 20 (4): 399-409.

Kompasiana.com. 2015. Kabupaten Tangerang Menyongsong Peran Kota Cerdas. [internet]. [diunduh 17 Januari 2018]. Tersedia pada: https://www.kompasiana. com/rushanovaly/kabupaten-tangerangmenyongsong-peran-kotacerdas.

Marzuki, A. 2018. Analisis Tingkat Perkembangan Wilayah, Konversi Lahan dan Rasio Tanah Terdaftar serta Arahan Pengembangan Wilayah Di Kabupaten Cirebon. [Tesis]. Bogor (ID): Sekolah Pascasarjana Institut Pertanian Bogor.

Panuju DR, Rustiadi E. 2013. Teknik Analisis Perencanaan Pengembangan Wilayah. Bogor (ID): Departemen Ilmu Tanah dan Sumberdaya Lahan, IPB.

[Pemkab Tangerang] Pemerintah Kabupaten Tangerang. 2009. Peraturan Daerah Kabupaten Tangerang Nomor 12 tahun 2009 tentang Rencana Pembangunan Jangka Panjang Daerah (RPJPD) Kabupaten Tangerang Tahun 2005-2015. Tangerang (ID): Pemkab Tangerang.

[Pemkab Tangerang] Pemerintah Kabupaten Tangerang. 2011. Peraturan Daerah Kabupaten Tangerang Nomor 13 tahun 2011 tentang Rencana Tata Ruang Wilayah Kabupaten Tangerang tahun 2011-2031. Tangerang (ID): Pemkab Tangerang.

Pribadi DO, Rustiadi E, Panuju DR, Pravitasari AE. 2017. Permodelan Perencaan Pengembangan Wilayah. Bogor (ID) : Crestpent Press P4W LPPM Institut Pertanian Bogor.

Rudiarto I, Handayani W, Wijaya HB. Pangi. 2017. Pola Ruang Lansekap Pedesaan: Penilaian Perubahan Guna Lahan dengan Indeks Vegetasi di Pedesaan Jawa Tengah. Jurnal Tata Loka. 19 (4): 280-290.

Rustiadi E, Saefulhakim S, Panuju DR. 2011. Perencanaan dan Pengembangan Wilayah. Jakarta (ID). Crestpent Press dan Yayasan Pustaka Obor Indonesia.

TangerangNews.com. 2018. Reses Ketua DPRD Tangerang Dibanjiri Keluhan Warga. [internet]. [diunduh 9 Juli 2018]. Tersedia pada: http://tangerangnews.com/ kabupaten-tangerang/read/24139/Reses-KetuaDPRD-Tangerang-Dibanjiri-Keluhan -Warga.

Trivinata R. 2016. Perencanaan Tata Ruang Bagian Wilayah Perkotaan Kepanjen. Studi tentang Konsistensi Pelaksanaan Rencana Detail Tata Ruang Bagian Wilayah Perkotaan Kepanjen Tahun 2014-2034. Jurnal Ilmiah Administrasi Publik (JIAP). 2 (8): 138-146. 